\title{
¿Entre Roma y Madrid?: \\ la reforma regalista y el Sínodo \\ de Charcas (1771-1773)
}

Elisa Luque Alcaide

Instituto de Historia de la Iglesia, Universidad de Navarra

En el contexto de las diversas interpretaciones historiográficas sobre la reforma eclesiástica americana del siglo XVIII, el artículo apunta la existencia de una corriente reformista autóctona. El Sínodo de Charcas (1771-1773) fue una iniciativa americana: lo convocó un obispo criollo antes de recibir el Tomo regio de Carlos III que pondría en marcha los concilios provinciales regalistas en América. El trabajo indaga las directrices reformistas del Sínodo en los decretos sobre párrocos y doctrineros. El estudio de la fuentes de esos decretos pone de relieve la recepción de los escritos de Benedicto XIV que, desde Roma, impulsó durante su pontificado (1740-1758) un movimiento de renovación cristiana. Los datos recogidos llevan a sostener que en el siglo XVIII existieron en América dos proyectos de reforma eclesiástica: uno regalista fraguado en Madrid y otro eclesial autóctono, en sintonía con las iniciativas de Roma y en continuidad con los concilios americanos de los siglos XVI y XVII.

El reformismo borbónico trató de hacer de la Iglesia americana uno de los pilares de la política colonial. El punto culminante del regalismo estatal lo representó la real cédula de Carlos III, del 21 de julio de 1769, conocida como el Tomo Regio, que puso en marcha la celebración de concilios provinciales en América. La respuesta fueron las cuatro asambleas conciliares que tuvieron lugar en las sedes metropolitanas de México (1771), Lima (1772), Charcas (1774-1778) y Santa Fé de Bogotá (1774).

\section{Debate historiográfico}

La historiografía ha apuntado diversas interpretaciones de las reformas eclesiásticas borbónicas en la América hispana. Manuel Giménez Fernández definió a los concilios americanos del XVIII como instrumentos regalistas para la sujeción de la Iglesia del Nuevo Mundo a la Corona. ${ }^{1} \mathrm{La}$

1 Giménez Fernández, Manuel: El Concilio IV Provincial Mejicano, Sevilla, 1939: según esta tesis los veía como instrumentos dirigidos a solicitar desde América la extinción de la Compañía de Jesús; los padres conciliares serían, así, la longa manus del Estado borbónico. 
historiografía jesuítica, siempre en la perspectiva de las relaciones IglesiaEstado, ha seguido la misma línea interpretativa. ${ }^{2}$ Alberto de la Hera, ha hecho una nueva lectura de los concilios carolinos americanos en los que ve un "experimento piloto" para implantar en la monarquía hispana una iglesia nacional autonómica en el seno de la Iglesia romana. La tradición del Patronato regio en América facilitaría esta primera experiencia que sería trasladada después a la Península. ${ }^{3}$

Algunos historiadores europeos y americanos han dado mayor peso a los protagonistas americanos del proceso reformador en el Nuevo Mundo. En la década de los años 60, desde 1962 a 1968, Bernard Bobb, ${ }^{4}$ y Asunción Lavrin, ${ }^{5}$ desde Estados Unidos, y Nancy Farris, ${ }^{6}$ en Inglaterra, apuntaron en esta dirección, siempre a partir del estudio de las relaciones Iglesia-Estado.

Con una perspectiva cultural y poniendo de relieve el componente americano del reformismo ilustrado en el Nuevo Mundo se sitúan las lecturas de Vicente Rodríguez Casado ${ }^{7}$ y de Mario Góngora; ${ }^{8}$ ambos autores desviaron el discurso de las reformas de las simples relaciones IglesiaEstado a un plano más ideológico. Luis Sierra, en su biografía de Lorenzana, ${ }^{9}$ el arzobispo de México que presidió el IV Concilio provincial,

2 "Los concilios provinciales de Indias eran arma de la política regalista durante el reinado de Carlos III; la utilizaron con criterio opostunista para acelerar la extinción de la Compañía". Lopetegui, León y Zubillaga, Félix: Historia de la Iglesia en la América española: desde el descubrimiento hasta comienzos del siglo XIX, Madrid, 1965, pág. 918. También Hera, Alberto de la, Sánchez Bella, Ismael y Díaz Rementería, Carlos: Historia del Derecho Indiano, Madrid, 1992, pág. 480.

3 Interpreta la promoción del arzobispo de México Lorenzana y del obispo de Puebla Fabián y Fuero, a las diócesis de Toledo y Valencia bajo esta óptica. Hera, Alberto de la: Iglesia y Corona en la América española, Madrid, 1992, pág. 479; también del mismo autor: "La renovación conciliar de la Iglesia indiana bajo Carlos III", en Actas y Estudios del IX Congreso del Instituto Internacional de Historia del Derecho Indiano, Madrid, 1991, t. II, págs. 541-560; y "El movimiento conciliar regalista en América", en Las relaciones entre la Iglesia y el Estado. Estudios en memoria del Profesor Pedro Lombardía, Madrid, 1989, págs. 1193-1229.

4 Bobb, Bernard: The Vicerregency of Antonio María de Bucareli in New Spain, 1771-1779, Austin, 1962.

5 Lavrin, Asunción: "Ecclesiastical Reform of Nunneries in New Spain in the Eighteenth Century”, en Hispanic American Historical Review, 46, Durham, N. C., 1996, págs. 371-393.

6 Farris, Nancy: Crown and Clergy in Colonial Mexico, 1759-1821: The Crisis of Ecclesiastical Privilege, London, 1968.

7 Rodríguez Casado, Vicente: "Notas sobre Iglesia y Estado, durante el reinado de Carlos III", en Revista de Indias, núms. 43-44, Madrid, 1951, págs. 89-109; y "El intento español de Ilustración cristiana", en Estudios Americanos, n. ${ }^{\circ}$ 9, 42, Sevilla, 1955, págs. 141-169.

8 Góngora, Mario: "Aspectos de la Ilustración católica en el pensamiento y la vida eclesiástica chilena" (1770-1814), en Historia, Instituto de Historia de la Universidad Católica de Chile, 8, Santiago de Chile, 1969, págs. 43-73.

9 Sierra Nava, Luis: El cardenal Lorenzana y la Ilustración, Madrid, 1975. 
subrayó el papel importante de este prelado, separándose de la tesis que veía a la jerarquía americana como longa manus de la Corona. Posteriormente, García Añoveros ha rechazado la visión de la Iglesia americana como víctima pasiva del poder del Estado en Indias. ${ }^{10}$

El estudio de las relaciones Iglesia-Estado, perspectiva preponderante en Farriss, ha marcado buena parte de la historiografía posterior. Se ha introducido, sin embargo, un nuevo componente en el debate historiográfico: el caracter autóctono o extranjerizante de las reformas eclesiásticas en la América ilustrada. David A. Brading caracteriza el proceso reformista en América como extranjerizante, ${ }^{11}$ en la medida en que que enfrentó a los peninsulares reformistas, con el sector criollo del clero. ${ }^{12}$

Teresa Y. Maya Sotomayor analiza los objetivos de los eclesiásticos ilustrados de Nueva España en el proyecto reformista ${ }^{13} \mathrm{y}$, en contra de la supuesta inefectividad del Concilio mexicano del XVIII, por la falta de aprobación oficial, ${ }^{14}$ sostiene que la escisión entre la religiosidad popular y barroca y la piedad filojansenista del alto clero, puesta de manifiesto en el Concilio, perfilaría la Iglesia del período independiente. ${ }^{15}$ Para Luisa Zahino Peñafort ${ }^{16}$ los Concilios americanos fueron medio extraordinario para lograr la extinción de la Compañía; y produjeron la oposición al poder peninsular de las clases alta y media criollas, y de la élite indígena, capita-

10 García Añoveros, Jesús María: La monarquía y la Iglesia en Madrid, Madrid, 1990.

11 Brading, David A.: Una Iglesia asediada: el Obispado de Michoacán, 1749-1810, México, 1994.

12 Brading, David A.: The First America: The Spanish Monarchy, Creole Patriots and the Liberal State, 1492-1867, Cambridge 1991, pág. 497.

13 Maya Sotomayor, Teresa Yolanda: Reconstruir la Iglesia: el modelo eclesial del episcopado novohispano, 1765-1804, México, 1997.

14 "Fue nula, o por lo menos de escaso relieve, la influencia de estos Concilios del siglo XVIII en la vida y disciplina eclesiástica hispanoamericana, si se exceptúa la del II de Charcas, del año 1774", afirma Antonio García. García y García, Antonio: "Las asambleas jerárquicas", en Borges, Pedro (dir.): Historia de la Iglesia en Hispanoamérica y Filipinas, t. I, Madrid, 1992, pág. 186.

15 Maya Sotomayor, Teresa Yolanda: Reconstruir la Iglesia..., pág. 21. La historiadora mexicana muestra que los Decretos conciliares de Lorenzana fueron utilizados por los sínodos y concilios mexicanos del siglo XIX. Los utilizó Fortino Hipólito Vera, para preparar el primer sínodo mexicano celebrado tras la independencia, el sínodo diocesano de Antequera de 1892, presidido por Eulogio Gillow, obispo de Oaxaca. Precisamente Vera en sus Apuntamientos sobre el Concilio del XVIII, mostró el trabajo que hizo sobre este Concilio. También lo hizo el obispo de Querétaro, Rafael Sabas Camacho, para preparar el primer concilio de la Iglesia mexicana, celebrado en México en 1896. Se trabajó sobre ellos en el Concilio de Guadalajara de 1897. Así pues, la Iglesia mexicana durante el porfiriato volvió a sacar los Decretos del Concilio de Lorenzana, que se proyectaron en la vida eclesiástica de la nación mexicana.

16 Zahino Peñafort, Luisa: Iglesia y sociedad en México, 1765-1800. Tradición, reforma y reacciones, México 1996. 
lina y rural, todas ellas vinculadas a los ignacianos. Oscar Mazín ${ }^{17}$ y William B. Taylor, ${ }^{18}$ han analizado las dimensiones y características del obispado michoacano, y del clero parroquial de México y Guadalajara.

En resumen, las reformas eclesiásticas americanas del siglo XVIII se han interpretado como instrumentos de la política del estado borbónico; como una labor extranjerizante, llevada a cabo por el clero peninsular, frente a las aspiraciones de los criollos; como el momento de escisión entre la religiosidad popular barroca y la piedad filojansenista de los estamentos cultos y del alto clero; y como un instrumento de cambio en el orden eclesial americano.

Una reciente investigación sobre las medidas acerca del clero secular adoptados por el Sínodo diocesano charquense de $1771-1773,{ }^{19}$ manifestó la existencia de un impulso de reforma surgido en la propia archidiócesis y la fuerte presencia en este proyecto reformista de la doctrina de Benedicto XIV (1740-1758) que, desde Roma, movía a una renovación eclesial. El trabajo que sigue aborda el tema de la reforma de la práctica religiosa y de la evangelización en ese mismo Sínodo de Charcas para verificar si, también en este campo, hay datos que permitan hablar de una reforma eclesiástica autóctona que recogería el impulso de Roma.

\section{Actividad sinodal en Charcas}

De los cuatro concilios americanos carolinos, tan sólo el de Charcas (1774 a 1778) fue precedido por un Sínodo diocesano que tuvo lugar entre los años 1771 y 1773 , convocado por iniciativa del arzobispo metropolitano. ${ }^{20}$

17 Mazín, Oscar: Entre dos majestades: el obispo y la Iglesia del Gran Michoacán ante las reformas borbónicas, México, 1987; y El cabildo catedral de Valladolid de Michoacán, México, 1996.

18 Taylor, William B.: Magistrates of the Sacred: Priests and Parishioners in EighteenthCentury Mexico, Stanford University Press, Stanford, 1996.

19 Luque Alcaide, Elisa: "Los decretos de reforma de la vida sacerdotal en el Sínodo de Charcas (1770-1773)", en Usunáriz Garayoa, Jesús M. (ed.): Historia y Humanismo. Estudios en honor del profesor Dr. D. Valentín Vázquez de Prada, vol. I, Pamplona 2000, págs. 361-388.

20 Hay pocos estudios sobre las asambleas eclesiásticas charquenses del s. XVIII. Castañeda, Paulino: "El sínodo de la Iglesia de Charcas de 1773", en Missionalia Hispanica, núms. 35-36, Madrid 1978-1979, págs. 91-135, aborda por vez primera el estudio del sínodo sobre la documentación del Archivo General de Indias; sobre el Concilio provincial de Charcas, de 1774, celebrado tras recibir el “Tomo Regio" carolino, Collado de Merino, M. ' Julia: Los Concilios de América bajo Carlos III, tesis doctoral, Pamplona 1987, pro manuscrito, la autora ha utilizado la versión de los Decretos del Concilio conservada en la Real Academia de la Historia (Madrid), Colección Mata Linares, tomo XXX (9/1685); y Soria-Vasco, J. Alejandro: Le Concile provincial de Charcas de 1774 et les déclarations des Droits de l'homme, en "L'Année Canonique", 15, París, 1971, págs. 481-524. Soria-Vasco ha trabajado la documentación del Concilio conservada en AGI, Indiferente General, 3026 A, 3026 B, 3041 y otros documentos de las secciones de Audiencia de Charcas, Lima y Buenos Aires. 
Así pues, en Charcas tuvieron lugar dos asambleas eclesiásticas sucesivas: un sínodo convocado por el prelado archidiocesano y un Concilio provincial posterior, en respuesta al Tomo Regio carolino.

El 4 de enero de 1765, el arzobispo de Charcas, Pedro Miguel de Argandoña, ${ }^{21}$ tras finalizar la visita pastoral de la archidiócesis, escribía al rey Carlos III solicitando la aprobación de la Corona para celebrar un sínodo diocesano. Una real cédula del 25 de febrero de 1767 accedía a la petición del prelado..$^{22}$

Charcas $^{23}$ era la sede metropolitana del Arzobispado de la Plata, del que formaban parte, además del territorio archidiocesano, los obispados de La Paz y de Santa Cruz, ambos en Bolivia; el de Asunción, en el Paraguay; Tucumán y Buenos Aires, en la actual Argentina. Es decir, se trataba de una vasta extensión que comprendía las actuales repúblicas de Bolivia, Paraguay, Uruguay y parte de Argentina.

Desde 1762 gobernaba la archidiócesis de Charcas el criollo Pedro Miguel de Argandoña y Pastén. Había trabajado antes en Chile, Ecuador y el Tucumán argentino, teniendo así experiencia directa de la América sudamericana. En Córdoba (Tucumán) había impulsado el seminario conciliar, redactando sus constituciones, y había promovido la evangelización de los indios pampas, que confió a los franciscanos. ${ }^{24}$ Promocionado en 1761 a la archidiócesis charquense, en 1763 inició la visita de las iglesias de la provincia, confirmando a 50.000 fieles y examinando de cerca la labor de setenta y cinco sacerdotes.

21 Pedro Miguel de Argandoña (ca. 1692-1775), natural de Córdoba de Tucumán (Argentina), donde había nacido en una familia de la alta administración estatal: su padre Tomás Félix de Argandoña, había sido gobernador de Tucumán. Se trasladó a Santiago de Chile para cursar estudios superiores en el colegio de San Miguel, de la Compañía de Jesús, centro de nivel superior, donde se doctoró en Teología en 1715; fue promovido a los 24 años, en 1716, a la canongía magistral de Santiago de Chile; y desempeñó el cargo de visitador general de la diócesis chilena, tras una estancia en Quito como cura doctoral de la diócesis quiteña. En 1745 fue promovido obispo de Tucumán, su ciudad natal, donde se destacó por su acusada impronta reformista. Impulsó las obras misionales apoyándose en los jesuitas. Tras visitar la diócesis centró sus esfuerzos en la mejora del clero diocesano, erigiendo el seminario conciliar y celebrando un Sínodo diocesano en 1751, del que publicó sus constituciones. En 1761 fue promovido a la diócesis de Charcas, tomando posesión en 1762. Zuretti, .Juan Carlos: Nueva Historia eclesiástica Argentina. Del Concilio de Trento al Vaticano II, Itinerarium, Buenos Aires, 1972, págs. 74 y 100.

22 Constituciones Sinodales del Arzobispo de la Plata, formadas por el Ilmo. Sr. Dr. D. Pedro Miguel de Argandoña Pastén, Cochabamba, 1854.

23 También recibió los nombres de Chuquisaca y de La Plata. Barnadas, Josep: Charcas: orígenes históricos de una sociedad colonial, La Paz, 1973.

24 Zuretti, Juan Carlos: Nueva Historia eclesiástica Argentina..., pág. 77. Para Zuretti, Argandoña sería un prelado regalista plegado a la Corona. Los datos que tenemos nos llevan a verlo como un prelado ilustrado, afecto a la Corona, pero dotado de cierta independencia de criterio. 
El arzobispo advirtió carencias que requerían remedio y decidió afrontarlas en un sínodo archidiocesano. Finalizada la visita pastoral, el 4 de enero de 1765, Argandoña escribió al rey solicitando la venia de la Corona para celebrar el sínodo. La petición fue aprobada por una real cédula del 25 de febrero de 1767. Carlos III, dos años después de dar vía al sínodo charquense, el 21 de agosto de 1769, firmaría el Tomo Regio, indicando a los prelados metropolitanos de América que celebrasen concilio provincial; esta cédula real fue recibida en Charcas en plena actividad sinodal, por lo que Argandoña solicitó y obtuvo de Madrid permiso para demorar la convocatoria del concilio provincial hasta finalizar el sínodo.

En Charcas se celebró un Sínodo diocesano que precedió al Concilio carolino de 1774; lo convocó un prelado criollo, que se propuso impulsar la reforma del arzobispado antes de recibir el Tomo Regio. Fue, pues, un evento eclesiástico en el que podremos estudiar las tendencias reformistas presentes en la diócesis en el último tercio del siglo XVIII. ${ }^{25}$ Los decretos sinodales de Charcas permitirían detectar el signo de la renovación eclesial buscada en La Plata.

\section{Objetivos y metodología del Sínodo}

El edicto de convocatoria del Sínodo, del 12 de octubre de 1770, puso en marcha los trabajos sinodales. El edicto iba acompañado de una carta circular de Argandoña al clero diocesano señalando los objetivos del Sínodo: mejorar la vida religiosa de los fieles e impulsar la evangelización. Una sana base económica en cada curato aseguraría la consecución de los objetivos.

El Proemio del libro I de las constituciones sinodales expresa que el trabajo sinodal se había apoyado sobre las orientaciones dadas por Próspero Lambertini, papa Benedicto XIV, ${ }^{26}$ en su obra De Synodo Dioece-

25 Luque Alcaide, Elisa: "Política eclesiástica de Carlos III en América: instancias de reforma en Charca", en García Jordán, Pilar et al. (coords.): Lo que duele es el olvido. Recuperando la memoria. América Latina, Barcelona, 1998, págs. 141-151.

26 Próspero Lambertini (1675-1758), nacido de una familia perteneciente a la nobleza de Bolonia, formado en el Colegio Clementino que los somascos dirigían en Roma, doctor en Derecho y en Teología por la Universidad de La Sapienza (1694), abogado consistorial y promotor de la fe durante veinte años; canónigo de San Pedro y consultor de varias congregaciones romanas, secretario de la Congregación del Concilio; obispo titular de Theodosia, es nombrado en 1727 arzobispo de Ancona; en 1728 recibe el cardenalato de Benedicto XIII; y en 1731 Clemente XII le nombra arzobispo de Bolonia, en donde permanece hasta que, en 1740, accede a la sede romana. Pío XII lo denominó el "più grande 
sana, ${ }^{27}$ acomodándola a la realidad americana. Próspero Lambertini, considerado el mejor canonista de la época, relanzó en su obra De Synodo Dioecesana las asambleas eclesiásticas trienales decretadas por Trento. El De Synodo recoge la doctrina canónica sobre el tema que señala su función eclesiástica. ${ }^{28}$

Lambertini salió al paso en el De synodo al proyecto de los absolutismos de Estado que, desde el último tercio del siglo XVII, convocaron asambleas eclesiásticas y promovieron sínodos y concilios para obtener la colaboración del clero en su proyecto de Iglesia nacional; ${ }^{29}$ estos proyectos abocaban a un episcopalismo defensor de ideas conciliaristas. ${ }^{30}$

Frente a una eclesiología de iglesias nacionales, el De synodo presentó la primacía del Papa destacando que la función del sínodo diocesano era legislar praeter y no contra el derecho común de la Iglesia. ${ }^{31}$ Esta doctrina sería de importancia primordial para los Concilios americanos del XVIII.

Lambertini, formado en un tomismo renovado, ${ }^{32}$ había participado como canonista al Sínodo reformista celebrado en Roma por Benedicto

Papa del secolo XVIII", "La figura e le opere di Benedetto XIV", in Discorsi e radiomessaggidi S.S. Pio XII, XX, 1959. La síntesis biográfica más completa es la de Rosa, Mario: Riformatori e ribelli nel '700 religioso italiano, Bari 1969; también Morelli, Emilia: Tre profili: Benedetto XIV, Pasquale Stanislao Mancini, Pietro Roselli, Roma, 1955, y Le lettere di Benedetto XIV al Card. de Tencin, Roma, 1955, 1965, 3 vols. VV. AA.: Benedetto XIV (Prospero Lambertini), Convegno Internazionale di studi storici, Cento 6-9 dicembre 1979, 2 vols. Centro Studi Girolamo Baruffaldi, 1971; Appolis, Emile: Entre jansenistes et zelanti."Tiers parti” catholique au XVIIIe. siècle, Paris, 1960.

27 Benedicto XIV: De Synodo Dioecesana, Editio novissima, Typographia Bassanensi, s.1., 1767 (Roma 1745). Esta obra había sido elaborada por Próspero Lambertini, siendo arzobispo de Bolonia, para preparar el sínodo que deseaba celebrar en la propia diócesis, y recogía las constituciones pontificias y las decisiones de las Congregaciones romanas sobre los temas que debían abordar esas asambleas diocesanas.

28 Hera, Alberto de la: Iglesia y Corona..., pág. 475-479.

29 Luis XIV logró en la Asamblea del clero francés de 1682, la aprobación de los artículos galicanos, que sostenían las "libertades" de la Iglesia francesa, limitando la autoridad del Papa respecto a los obispos franceses; y situándolos bajo el control de la Corona. Roma protestó contra esta medida, condenada por Alejandro VIII en la bula Inter multiplices, de 1690; en el siglo XVIII, seguirían este camino España y Toscana.

30 El febronianismo centroeuropeo coincidía en esta orientación. Juan Nicolás de Honthein (1701-1790), en su De statu ecclesiae et legitima potestate Romani pontificis liber singulares ad reuniendos dissidentes in religione christianos compositus, publicada en 1743 bajo el seudónimo de Febronius, planteaba una Iglesia apoyada sobre el colegio episcopal, del que el Papa sería "primum inter pares", residiendo en el concilio la suprema autoridad.

31 En su libro IX afrontaba el tema de cómo el sínodo debía evitar pronunciarse sobre los temas reservados a la Sede apostólica. Con esta obra Lambertini apunta a la doctrina que sería definida por el Vaticano I en 1870. Cfr. Naz, R.: Dictionnaire de Droit Canonique, ad vocem.

32 Luque Alcaide, Elisa: "Il tomismo romano nel settecento: San Tommaso nel Bullario di Benedetto XIV", en Atti del IX Congresso Tomistico Internazionale, Città del Vaticano 1991, VI, págs. 231-245. 
XIII en $1725 .{ }^{33}$ En su De Synodo se perciben fermentos de renovación de la vida eclesiástica y religiosa, dando valor y espontaneidad a la experiencia pastoral diocesana. ${ }^{34}$ Ya en la sede romana, Benedicto XIV, promovió una llamada a la reforma de la vida cristiana pilotada por los prelados diocesanos y apoyada sobre un clero secular de buen nivel. Pues bien, la diócesis de Charcas recurrió al modelo sinodal trazado por Lambertini, antes de la convocatoria conciliar regalista de Carlos III.

Para afrontar en el Sínodo las necesidades de la archidiócesis, Argandoña pidió a los párrocos que informaran de la labor de su distrito. ${ }^{35}$ Además de los métodos evangelizadores, debían reflejar si impartían la catequesis en las lenguas indígenas y si lo hacían con la frecuencia señalada. Los datos enviados pasarían a los peritos del Sínodo que los tendrían en cuenta para elaborar sus propuestas. ${ }^{36}$

La mitra de Charcas se propuso con el trabajo sinodal relanzar la práctica religiosa y la evangelización: ambas tareas son responsabilidad directa de los párrocos y los doctrineros de indios. De ahí que los decretos del

33 Relanzó este sínodo los temas de la reforma tridentina: los deberes pastorales del obispo, la obligación de residencia de obispos y párrocos, la instrucción religiosa, la fundación de seminarios, creando para esto último una especial congregación de seminarios. Cfr. Jedin, Hubert: Manual de Historia de la Iglesia, Barcelona 1978, VI, pág. 800, y Donati, Claudio: "Dalla 'Regolata devozione' al 'Giuseppinismo’”, en Rosa, Mario (coord.), Cattolicesimo e lumi nel settecento italiano, Roma, 1981, pág. 78; Fiorani, Luigi: Il Concilio romano del 1725, Roma, 1978.

34 Rosa, Mario: Riformatori e ribelli..., págs. 51-52.

35 Los temas eran: 1. Número de almas a su cargo: harían el padrón. 2. Extensión y límites de sus beneficios. 3. Número de viceparroquias o capillas. 4. Número de cofradías y sus ingresos. 5. Rentas de las parroquias para costear la luz del Santísimo, los vasos sagrados, etc. 6. Del modo como adoctrinaban a sus feligreses, principalmente a los Indios, y si, "como es justo, por sus propias personas o por la de sus ayudantes les instruyen en los misterios de la santa fe en su propio idioma"; "si tienen personas instruidas y examinadas que adoctrinen a la juventud de ambos sexos todos los días, como es de su obligación; y si a los demás se les enseña, no sólo los domingos y días de precepto, sino también los miércoles y viernes conforme a la ordenanza"; si no se hace así deberían informar debidamente. 7. De cómo corregían los desórdenes: haciendo hincapié en agüeros, adivinaciones, sortilegios, ídolos y medios para corregirlos. 8. Del número de ayudantes que tenían, según las distancias de las doctrinas. 9. De los clérigos vagabundos. Importancia de este punto para tomar medidas que evitasen el mal ejemplo de los eclesiásticos. 10. "De las conferencias morales para los clérigos seculares, en los lugares donde el número de sacerdotes es suficiente para ello". 11. Sobre los derechos parroquiales en los entierros. 12. Si se llevaba el viático a los enfermos que lo pedían. 13. De las fincas y bienes raíces que pudieran tener sus iglesias en iglesias en concepto de dotación. 14. De los ingresos que tuviesen asignados cada una de sus doctrinas.

36 Parece que efectivamente los curas se pusieron manos a la obra y se contó con sus informes para el trabajo del Sínodo. La "Relación de estaciones del Sínodo", relata que aunque se había convocado primero para el día 8 de junio de 1771, "en atención a no haber acabado de llegar los informes e instrucciones que se pidieron a los Curas se prolongó hasta el día ocho de agosto del mismo año, y por otros justos y legítimos embarazos que sobrevinieron se volvió a prorrogar hasta el veinte del citado mes de agosto", en Constituciones Sinodales del Arzobispo de la Plata, pág. 14 
Sínodo charquense, dedicados al oficio de párroco, ${ }^{37}$ aparecían significativos para detectar el sentido de la reforma emprendida. La importancia del párroco en la vida colonial ha sido puesta de manifiesto por la historiografía. La política borbónica se propuso ceñir la función del párroco a lo estrictamente espiritual $;^{38}$ frente a ello, los padres sinodales charquenses, apoyados en una praxis arraigada desde los inicios de la Iglesia en América, afirmaron que les correspondía a los párrocos "el gobierno de sus súbditos, no sólo en lo espiritual, sino también en lo temporal en cuanto conduzca al bien y provecho de las almas" (lib. I, tít. 8, cap. 2).

\section{Impulso a la práctica religiosa de los fieles}

Ante todo, se deduce de las constituciones sinodales que el cristianismo estaba asentado en las ciudades y pueblos del territorio. Sin embargo, había de mejorar en diversos aspectos. Los fieles necesitaban incrementar el conocimiento de la doctrina de la fe "cimiento de la vida cristiana" (lib. I, tít.1, cap.1) y aumentar la práctica sacramental. Una buena parte del sector popular de la ciudad de Charcas, no sólo de los forasteros y viajeros, no vivía el precepto pascual. De ese dato deducen los sinodales que ocurriría lo mismo en las villas de Potosí, Oruro, Cochabamba y Tarija (lib. I, tít. 8, cap. 11); muchos fieles no recibían el sacramento de la confirmación, porque desconocían la doctrina acerca del mismo y, por ello, el sínodo insiste a los párrocos que la enseñasen a sus feligreses (lib.I. tít. 5, cap.1).

Aparece un dato positivo: en la capital estaba muy arraigada la Escuela de Cristo. Era una asociación piadosa que organizaba en la catedral un acto de culto ante el santísimo todos los jueves, que comprendía también una plática sobre la doctrina de la fe; a estos actos asistían un número considerable de fieles, muchos de ellos "gente pobre", y con una alta participación de mujeres. El Sínodo favorece esta actividad, para ello se decidió que ese día se cerrase la catedral más tarde del horario establecido por la asamblea para las iglesias, con el fin de que pudieran asistir quienes regresaban de sus trabajos (Congregación 19).

37 Título VIII del libro I de las Constituciones, De officio Rectoris, compuesto de veintiseis capítulos; se debatió su contenido en las $6 .^{\mathrm{a}}$ y $7 .^{\mathrm{a}}$ congregaciones celebrada el 25 de septiembre y el 2 de octubre de 1771, aprobándose en esta última sesión. Ibídem, págs. 24 y 25.

38 Taylor, William B., "El camino de los curas y de los Borbones hacia la modernidad", en Álvaro Matute, et al. (coords.), Estado, Iglesia y Sociedad en México. Siglo XIX, México, 1995, págs. 81-113. 
Para afrontar la necesidad de instrucción cristiana el Sínodo renovó las medidas de Trento y de los concilios limenses que aplicaron el tridentino: la catequesis continuada a niños y jóvenes, al menos una vez por semana, y la predicación a los adultos en las misas de los domingos y días de fiesta (lib. I, tít. 8, cap. 2). Además decretó que los párrocos hicieran en voz alta juntamente con los fieles un acto de fe, esperanza y caridad al terminar la misa, como había prescrito Benedicto XIV (libro I, tít. 8, cap. 1). ${ }^{39}$

En un siglo en que el pauperismo se había acrecentado, se estudió el modo más eficaz de transmitir la doctrina a los mendigos. En concreto, en la ciudad de Charcas se solía organizar en la casa arzobispal una catequesis el día de la semana en que acudían a recibir limosna. La tercera congregación sinodal decidió que se impartiera en tres puntos de la ciudad: en las parroquias del Sagrario, de San Sebastián y de San Lázaro. Se alertaba respecto a los falsos mendigos: quienes no tenían impedimentos para trabajar no deberían recibir esa ayuda material, antes bien, había que instarles a desempeñar un oficio. El absentismo laboral era un "vicio (...) común en la ciudad y villas de la archidiócesis y para exterminarlo los sinodales exhortan a los justicias reales a que pongan los medios oportunos para erradicarlo" (lib. I, tit 8, cap. 20)

Llama la atención el desarrollo que presenta en las constituciones de Charcas la doctrina sobre la misa, recogiendo documentos lambertinianos. Le dedicaron tres capítulos del Título 8. El capítulo 5, exhortaba a los párrocos a fomentar en los fieles una activa participación en la misa. Para ello les deberían enseñar que el sacrificio de la cruz que la misa renueva "no sólo lo ofrece el sacerdote, sino también todos los cristianos, especialmente los que se hallan presentes". El capítulo 9, recogía la obligación del párroco de ofrecer por sus feligreses la misa de los domingos y días festivos. ${ }^{40} \mathrm{El} 10$ señalaba los casos en que se permitía a los párrocos celebrar dos misas en un sólo día para facilitar la asistencia de los fieles. ${ }^{41}$ Destaca así, la exposición sinodal de la renovación incruenta del misterio de la cruz que realiza cada misa y su insistencia para que los fieles participasen de modo consciente en esta realidad.

Estas medidas fueron acompañadas de indicaciones litúrgicas para resaltar la dignidad del culto. Las imágenes de las iglesias debían estar

39 Destaca el sínodo la importancia de que con esta práctica se ejercitan los fieles "a hacerlos con la frecuencia que conviene" y remite a Benedicto XIV, Constitución Etsi minime y Constitución Cum religiosi e Institutiones, LXXII, n. 21.

40 Lo apoya en la constitución Cum semper, de Benedicto XIV.

41 Apoyado en la constitución Declarasti nobis, de Benedicto XIV. 
"pintadas y adornadas de modo que muevan al culto"; las tallas de bulto de los altares y las procesionales deberían vestirse del modo que es tradición de la Iglesia universal (lib. I, tít. 8, cap. 8). ${ }^{42}$

El sínodo promovió la piedad de los fieles. Ante todo, la devoción a la Madre de Dios: se concedieron indulgencias al rezo del rosario en las parroquias y en las familias; todos los sábados del año se celebraría una misa votiva de la Virgen y se cantaría la Salve (lib. I, tít. 8, cap. 6). Recordó la intercesión del ángel custodio y de los santos; a éstos últimos los presentaba como modelos de los cristianos y recomendó tener sus imágenes en las casas.

\section{El cristianismo de los indígenas}

Las constituciones charquenses reflejan un panorama bipolar respecto a los indígenas: los que habitaban en ciudades y pueblos estaban bautizados; por contraste, aparece difícil la cristianización de los que vivían esparcidos por las montañas. La política de la Corona a favor de la reducción de los naturales no había tenido efecto. ${ }^{43} \mathrm{El}$ sínodo optó por favorecer la reducción a poblados y recordó a los doctrineros que debían promoverla por la persuasión evitando la coacción de corregidores, justicias y caciques, que convertía en pernicioso lo que estaba pensado para ayudar a los naturales (lib.I, tít. 8, cap. 14).

En el Sínodo aparecen las tensiones que en esos años vivían los indígenas. La aplicación del proyecto colonial borbónico en América cargó más el tributo de los naturales y habían estallado una serie de revueltas. En la provincia de Sicasica en 1770, habían matado a uno de los corregidores; el año siguiente, 1771, los indios de la provincia de Pacajes se levantaron también contra el corregidor y la protesta se extendió a diversos lugares. Sólo la intervención del cura del lugar logró restablecer el orden. ${ }^{44}$

42 En este punto remiten a la obra escrita por Lambertini, Próspero: De servorum Dei beatificatione, (Bologna, 1734-1738), Typographia Bassanensi, s.1., 1766, lib. 4, p. 2, cap. 21.

43 (La Ordenanza) "que manda se reduzcan los indios a poblaciones lo que no ha tenido efecto" Tercera congregación, en Constituciones, pág. 21. Sobre el tema de las reducciones: véanse Pedro Borges Morán, Misión y civilización en América, Madrid, 1987; Ernesto de la Torre Villar, "Las congregaciones de indios como una fase de la política de la población y colonización en América", en Estudios sobre política indigenista española en América, t. I, Universidad de Valladolid, Valladolid, 1975, págs. 313-329; Magnus Mörner: La Corona española y los foráneos en los pueblos de indios de América, Stockholm, 1970.

44 Avala así la autoridad moral del doctrinero. Sobre estos sucesos, Soria-Vasco, Alejandro: Le Concile provincial de Charcas de 1774, pág. 490. 
Denunciaron los sinodales los abusos a los indios de las minas de Potosí: los azogueros les obligaban a trabajar los días de fiesta. El Sínodo recordó que, si la Iglesia permitió a los indígenas que pudieran trabajar en algunas fiestas, lo hizo para que trabajaran sus propiedades y no las de criollos y españoles. ${ }^{45}$

Las constituciones sinodales recogen datos de reivindicaciones de los indígenas: lógicamente son aquellas en que el encausado era el cura del lugar. Los indios de Carasi recurrieron al sínodo para que declarase que no estaban obligados a contribuir a la fábrica de la iglesia; el cura debería costear estos gastos de los propios aranceles sinodales. El sínodo rechazó la petición porque este gasto no estaba previsto en el arancel y desde tiempo inmemorial se cubría con las ofertas de los fieles. El sínodo añadía que, si los de Carasi se resistían a lo indicado, "no se les hiciera la menor extorsión", y se informara a la asamblea sinodal para determinar cómo proceder. En contraste con esta mesura, condenaron a la pena de doce azotes a los indios Pascual Choque y Diego Carvajal "por haber sembrado con sus respectivas quejas, notables alborotos e inquietudes que se habían propagado en casi todos los curatos, (...) para escarmiento de los demás". ${ }^{46}$

Los indígenas bautizados conservaban restos de sus antiguas idolatrías. De otra parte, ya no aparecen como una población sumisa, como en minoría de edad, que reflejaban algunos relatos misionales de primera hora: eran hombres que reclamaban sus derechos. Se imponía relanzar una evangelización más profunda. ${ }^{47}$ El sínodo la apoyó sobre un clero secular con buena preparación. Los datos barajados en las constituciones sinodales dan a entender que los párrocos y doctrineros debían ser más celosos en esta labor. Se instó a los doctrineros a que atendieran a quienes habitaban en lugares remotos e hicieron especial énfasis en su deber de acudir a los moribundos (lib. I, tít. 8, cap.14).

El proyecto inicial charquense se propuso enseñar el catecismo en lengua indígena, los doctrineros debían conocerla para acceder a su nombramiento. Pero los decretos sinodales se escribieron después de recibirse en la diócesis el Tomo Regio, que imponía la castellanización; los redactores optaron por una vía media: la catequesis se debía hacer en los dos idio-

45 Octava congregación. Constituciones., pág. 25. También denunció el abuso de caciques y principales que les vendían vino, dando pie así al arraigo de la embriaguez (lib. I, tít. 8, cap. 3)

46 XIII Congregación, en Constituciones, págs. 28-29.

47 Establecen que dediquen más tiempo a esta labor: los adultos recibirán la doctrina dos días semanales, además de los domingos; los niños tendrán catecismo todos los días del año (lib. I, tít. 1, cap. 3) 
mas, aunque a los más pequeños se les enseñaría en castellano (lib. I, tit 8 , cap. 15 y lib. I, tít. 1, cap. 3).

El sínodo había subrayado la importancia de la participación activa de los fieles en la misa. Especialmente lo debían procurar los curas de los indígenas (lib. I, tít., 8, cap. 5). Debían poner los medios para que pudieran asistir a misa en los días de precepto; en concreto, deberían impedir que los caciques les cobrasen los tributos en ese tiempo (lib. I, tít. 8, cap. 13) Asimismo, destacó la importancia de que en las iglesias de las doctrinas se cuidase la dignidad de las imágenes y pinturas ya que eran "historia y libro donde se lee y considera lo que se ha de imitar y seguir"; prohibió que los fieles llevasen a sus casas las imágenes procesionales, para cortar así "la superstición de celebrar sus ídolos colocándolos en los propios huecos de las peanas de los santos" (lib. I, tít. 8, cap. 8).

Los indígenas acudían a confesarse. Habían llegado noticias al sínodo de que en algunas doctrinas los curas no los recibían con agrado si lo hacían a horas intempestivas, y les reprendían con acritud para que acudieran de día. Un decreto sinodal instaba vivamente a los curas a atender con solicitud al que pedía confesarse a cualquier hora, de este modo facilitarían que recurriesen al sacramento en caso de necesidad (lib. I, tít. 8, cap. 16). En cambio, no solían recibir la comunión y los padres sinodales veían en esto "una de las causas por que muchos indios no están arraigados y fundados (...) en la fe católica". En las constituciones se exhortaba a los curas para que enseñaran la grandeza de este soberano misterio (lib. I, tít. 8, cap. 12).

Promueven especialmente la devoción a la Virgen que apartaba a los naturales de las idolatrías (lib.I, tít. 8, cap. 6). Acerca de los santos debían enseñar los párrocos que "no son dioses, error en que aún se mantienen muchos de ellos (...) de forma que queden persuadidos, que aunque en memoria suya se celebren misas, el sacrificio no se ofrece a ellos, sino a sólo Dios" (lib. I, tít. 8, cap. 7)

\section{Fuentes doctrinales del texto sinodal charquense: presencia de Roma en Charcas}

Aparece, en los apartados anteriores un plan de reforma intraeclesial. Charcas apoya sobre el clero parroquial secular la renovación de la vida cristiana de los fieles. Se recoge, a continuación, la enumeración de las citas que sostienen este proyecto. 
Citas del libro I, título 8 De officio Rectoris de las Constituciones sinodales de Charcas

Benedicto XIV:

21 citas

De Synodo Dioecesana

De servorum Dei beatificatione

2 citas

Institutiones eccclesiasticae

1 cita

7 citas

Constitución Ubi primum

2 citas

Constitución Etsi minime

2 citas

Constitución Cum religiosi

2 citas

Constitución Cum semper

6 citas

Constitución Declarasti nobis

1 cita

Concilio Trento

Decretos De reformatione

8 citas

1 cita

Concilio IV Milán

4 citas

Concilio II Limense (1565)

Concilio III Limense (1583)

11 citas

Sínodo Limense (1588)

Sínodo Limense (1590)

1 cita

1 cita

1 cita

Sínodo Limense (1592)

4 citas

Sínodo Limense (1613)

12 citas

Sínodo de Arequipa (1684)

11 citas

Sínodo de Caracas (1687)

12 citas

Sagrados Cánones

passim

Recopilación de Indias (1681)

19 citas

Recopilación de Castilla

3 citas

Ordenanzas del Duque de la Palata (20-II-1684)

4 citas

Otros Papas y prelados citados

San Carlos Borromeo (1538-1584)

1 cita

Clemente VIII (1592-1605)

1 cita

Paulo V (1605-1621)

1 cita

Urbano VIII (1623-1644)

1 cita

Teólogos y canonistas

San Agustín

San Gregorio Magno

1 cita

1 cita 
¿ENTRE ROMA Y MADRID?: LA REFORMA REGALISTA

Reyna $^{48}$
Montenegro $^{49}$
Vega $^{50}$
Barbosa $^{51}$
Reinsseat $^{52}$
Ferraris $^{53}$
Solórzano $^{54}$

Reyna $^{48}$

Montenegro ${ }^{49}$

Vega $^{50}$

Barbosa $^{51}$

Ferraris $^{53}$

Solórzano $\begin{aligned} & 18 \text { citas } \\ & 9 \text { citas } \\ & 4 \text { citas } \\ & 4 \text { citas } \\ & 2 \text { citas } \\ & 1 \text { cita } \\ & 2 \text { citas }\end{aligned}$

48 Pedro de Reyna Maldonado, canónigo peruano, autor de Norte claro del perfecto prelado en su Pastoral gobierno, 2 vols., publicado en Madrid en 1653, y dedicado al Supremo y Real Consejo de Indias.

49 Alonso de la Peña y Montenegro (+1687), formado en la Universidad de Santiago de Compostela y después en la de Salamanca, fue catedrático de Escritura de la Universidad de Santiago de Compostela; en 1653 fue promocionado como obispo de Quito, en donde permaneció hasta su muerte. Autor de Itinerario para parrocos de indios. En que se tratan las materias más particulares, tocantes a ellos, para su buena administración, Madrid 1668, con numerosas reediciones. Sobre ello Saranyana, Josep Ignasi (dir.): Teología en América Latina, I, Desde los inicios hasta la Guerra de sucesión, Frankfurt-Madrid, 1999, págs. 464-470.

50 Feliciano de Vega (Lima - Acapulco 1640), licenciado en Cánones por la Universidad de San Marcos, de Lima, en donde regentó la cátedra de Leyes y, posteriormente la de Prima de Cánones; siendo catedrático de Prima de Cánones, fundó una cátedra de Teología Moral, asignándola a los dominicos (Meléndez, Juan de: Tesoros verdaderos de las Indias en la Historia de la gran Provincia de san Juan Bautista del Perú, Impr. Nicolás Ángel Tinassio, Roma 1681 y 1682, aquí t. I, lib.I, cap. 9); fue preconizado obispo de Popayán en 1631, pasando a La Paz en 1633, y al arzobispado de México en 1638, aunque murió antes de tomar posesión de la mitra mexicana. Perito canonista se encuentran entre sus obras las Relectiones canonicae in secundum decretalium librum, Lima 1633 (abarca sólo el título De iudices y el De foro competenti); también publicó las Constituciones synodales del obispado de Nuestras Señora de la Paz en el Perú, Lima 1639. Sobre ello, Egaña, Antonio de: Historia de la Iglesia en la América española. Hemisferio Sur, Madrid, 1966, págs. 376-377.

51 Agustin Barbosa (1589-1649), nacido en Guimarães, Portugal y fallecido en Roma, Protonotario apostólico y consultor del Indice, ha sido considerado el primer canonista de su tiempo. Hacia 1632 se traslada a Madrid como juez de causas eclesiásticas; Felipe IV lo promueve como obispo de Ugento, Italia meridional, fue consagrado en Roma el 22 de marzo de 1649, pero fallece poco después. Su obra Iuris ecclesiastici universi, libri III, publicada en Lyon, 1645, recoge en su conjunto el derecho pontifical; publicó también Colecciones de decisiones de la Sede apostólica, y pareceres de canonistas, sobre las cuestiones tratadas por el Concilio tridentino; así como una obra sobre los deberes del obispo, publicada en Paris, en 1625. La Colección completa de sus obras fue publicada en Lyon, en 1716, en 16 vols.: Raffalli, J., en Naz, R.: Dictionnaire de Droit Canonique, T. II, col. 203.

52 Anacleto Reinffenstuel (ca 1642-1703), ofm, alemán de Baviera, profesor de filosofía en Landschut (1667) y Munich (1668), y de teología en 1671 y 1675 en ambas universidades; fue también definidor de su provincia. Impulsor de la división temática de la teología práctica, fue profesor de derecho canónico en Freising. Es autor de una Theologia moralis, publicada en Munich en 1692, con sucesivas adiciones, en la que se inclina por el probabilismo. Para el objeto de nuestro estudio se utiliza su Jus canonicum universum, enciclopedia de derecho canónico, aparecida en Munich 1700-1714, y con mumerosas reediciones. Publicó también Praxis compendiosa sacrorum rituu et caeremoniarum, Munich, 1670, destinada a unificar la liturgia en la orden de los fraile menores: Naz, R.: Dictionnaire de Droit Canonique, VII, col. 547-548.

53 Lucio Ferraris (+1763), ofm, nacido en Solero, cerca de Alejandría, lector en teología, y consultor del Santo oficio. Su obra más conocida es la Prompta bibliotheca canonica, juridica, moralis, theologica necnon ascetica, polemica, rubristica, historica, 8 vols., Francesco Storti, Bologna 1746, 
En los datos anteriores destaca la presencia de la doctrina de Benedicto XIV, papa todavía reciente, fallecido en 1758 . El proyecto sinodal se había propuesto seguir las orientaciones del De Synodo Dioecesana, y efectivamente la asamblea de Charcas lo hizo así. Fue el papa más abundantemente citado. El Sínodo de Charcas se apoyó en el modelo sinodal lambertiniano..$^{55}$

Se recogen, además, citas del De servorum Dei beatificatione ${ }^{56}$ y las Institutiones eccclesiasticae ${ }^{57}$ de Lambertini. Aparecen referencias a cinco encíclicas lambertinianas. Tres de ellas trataban de la instrucción a los fieles: la Ubi primum, del 3 de diciembre de $1740,{ }^{58}$ que apoyaba la catequesis sobre un clero secular de calidad; la Etsi minime, del 7 de febrero de $1742 ; 59$ y la Cum religiosi, del 26 de junio de $1754 .{ }^{60}$ Las otras dos encíclí-

que fue reeditada numerosas veces en el siglo XVIII y también a finales del XIX. Bajo la forma de un diccionario alfabético que, según Schulte presenta una indiscutible utilidad práctica, y, al mismo tiempo, una dispersión temática. En cualquier caso en el tiempo del Sínodo charquense era, tanto en Europa como en América, una obra de referencia obligada para la temática: Cfr. Lepointe, G.: en Naz, R.: Dictionnaire de Droit Canonique, V, ad vocem.

54 Juan de Solórzano Pereira (1575-1654), jurista, catedrático de Salamanca y oidor en Lima, recibió el encargo del conde de Lemos de formar una recopilación de las leyes de Indias. Solórzano lo hizo a base de los cedularios impresos y de los registros de cédulas de la Audiencia de Lima. El proyecto se componía de seis libros, de los que sólo se redactó el primero. El sínodo cita su obra Política Indiana, publicada en 1647.

55 A la hora de redactar las Constituciones los charquenses siguen también las orientaciones lambertinianas que aconsejaban hacerlo a modo de instrucción, detallando la doctrina en casos de prolongado vacío sinodal (De Synodo Dioecesana, lib. 6, cap. 2, n. 2). En Charcas había transcurrido más de siglo y medio desde el último sínodo; y el texto sinodal se redacta las charquenses con una amplitud que permite apreciar la doctrina sinodal.

56 Citado en nota 42. Esta obra recogía la praxis eclesiástica sobre los procesos de canonización y profundizaba, a la vez, en la doctrina de las virtudes heroicas y de las gracias gratis datae impulsando con ello la interiorización de la vida cristiana: Hertling, L. Benoit XIV, DSp., I.

57 Conferencias de teología pastoral y de derecho canónico, sobre temas relacionados con la vida cristiana de los fieles y la labor pastoral del clero: Benedicti XIV, Pastoral e Instrucciones Eclesiásticas de... siendo Cardenal Arzobispo de Bolonia, t. II, Imprenta Real, Madrid, 1787.

58 "Melius enim profecto est pauciores haberes Ministros, sed probos, sed idoneos, atque utiles, quam plures, qui in aedificationem Corporis Christi, quod est Ecclesia, nequicquam sint valituri": Bullarium Benedicti PP. XIV, t. I, Typis Congregationis de Propaganda Fide, Roma 1746, págs. 4-8: La Ubi primum urgía a erigir seminarios, donde aún no existieran y el Sínodo de Charcas se hizo eco impulsando el que ya existía en la diócesis : confirmó las constituciones, dadas en 1708 por D. Juan Queipo de Llano y Valdez, obispo anterior a Argandoña, y determinó, además, las condiciones requeridas para obtener las becas, el uso del vestido talar y las costumbres cotidianas del centro.

59 En ella el papa acude como paradigma de obispo pastor al prelado del Perú Toribio de Mogrovejo, junto con Carlos Borromeo y Francisco de Sales (pág. 114). Bullarium Benedicti PP. XIV, t. I, págs. 110-115.

60 Bullarium Benedicti PP. XIV, 1757, t. IV, págs. 213-218: aconseja el método agustiniano expuesto en el cap. 10 del De catechizandis rudibus: establecer un diálogo familiar del catequista con el catequizado, después de la explicación doctrinal, que permita cerciorarse de si ha entendido lo expuesto o necesita volver sobre el tema (pág. 218). 
cas citadas tratan de la misa: la Cum semper, del 19 de agosto de 1744, ${ }^{61}$ y la Declarasti nobis, del 16 de marzo de $1746 .{ }^{62}$

El Concilio de Trento está presente con ocho referencias. Los sinodales charquenses recogen el Concilio provincial de Milán, celebrado por Carlos Borromeo para poner en marcha en la diócesis el proyecto tridentino.

$$
* * *
$$

El Sínodo de Charcas trabaja asimismo con los concilios y sínodos americanos del Sur del continente. Ante todo, los de Lima, la diócesis matriz de la charquense. Aparece el II Limense (1565), presidido por Jerónimo de Loaysa, receptor de los decretos tridentinos, recién llegados a América. Hay una destacada presencia de las asambleas celebradas por Toribio de Mogrovejo que supusieron la aplicación madura de las orientaciones tridentinas. El más citado es el III Limense, convocado y presidido por Mogrovejo en 1582-83, del que partió, como es conocido, un renovado impulso evangelizador en las lenguas vernáculas; también tres Sínodos limenses posteriores del mismo arzobispo Mogrovejo, los de 1588, 1590 y 1592; y el Sínodo limense de 1613 , convocado por Lobo Guerrero. ${ }^{63}$ De los sínodos americanos destacan la impronta del Sínodo de La Paz, de 1638, celebrado por Feliciano de Vega, ${ }^{64}$ buen canonista; la del arequipense de 1684, presidido por Antonio de León; ${ }^{65}$ y la del celebrado en Caracas

61 Sobre la obligación de los párrocos de celebrar y aplicar por sus feligreses la misa parroquial de los días festivos; recuerda el deber del párroco de predicar la doctrina y de impartir catequesis; y hacía también un llamamiento sobre el cuidado del culto, subrayando la importancia del canto litúrgico: Benedicto XIV, Colección en latín y castellano de las Bulas, Constituciones, encíclicas, breves y decretos del Stmo. Padre... [según la auténtica edición romana del Bulario, de 1760], t. I, Antonio Espinosa, Madrid 1791 (aquí, pág. 191).

62 Sobre las condiciones requeridas para que un sacerdote pudiera celebrar dos misas en un mismo día por necesidades pastorales; en diversas ocasiones alude a lo determinado por el Sínodo limense de 1592, celebrado por Toribio de Mogrovejo: Bullarium Benedicti PP. XIV, Bartholomaei Occhi, Venetiis, 1768, t. II, págs. 7-10.

63 En el sínodo de 1613, presidido por Bartolomé Lobo y Guerrero, intervino activamente Feliciano de Vega, el que después convocaría el Sínodo de La Paz.

64 El Sínodo de Charcas remite a las Constituciones synodales del obispado de Nuestras Señora de la Paz en el Perú, publicadas por Vega en Lima el año 1639, citada en 50.

65 Antonio de León, madrileño que estuvo al frente de la diócesis arequipeña desde 1679, llevó a cabo una labor pastoral importante, con acento en la evangelización educadora y en la formación del clero diocesano. Ambas dimensiones están presentes en las actas sinodales, que fueron impresas en Lima en 1688: Egaña, Antonio de: Historia de la Iglesia en la América española. Hemisferio Sur..., págs. 326-329. Vargas Ugarte destacaba ya su labor con los sacerdotes diocesanos; fue el introductor en la diócesis de las conferencias para el clero. El sínodo arequipense de 1684 se apoyó en Trento, en el III Concilio provincial limense (1582-1583) y en las sinodales de Lobo Guerrero (1613): Vargas Ugarte, Rubén: Historia de la Iglesia en el Perú, III, Aldecoa, Burgos, 1960, págs. 355-357. 
en 1687, convocado por Diego de Baños y Sotomayor. ${ }^{66}$ Se constata la continuidad de las asambleas eclesiásticas de la América del Sur.

Todos los teólogos y canonistas citados son anteriores al siglo XVIII. Entre los americanos el mayor número de citas corresponde al canónigo peruano Pedro de Reyna Maldonado, en su obra Norte claro del perfecto prelado en su Pastoral gobierno,${ }^{67} \mathrm{y}$ le sigue Alonso de la Peña y Montenegro, en su obra Itinerario para parrocos de indios. En que se tratan las materias más particulares, tocantes a ellos, para su buena administración. ${ }^{68}$

Aparecen también canonistas europeos: el portugués Agustín Barbosa, considerado el primer canonista de su tiempo, que en su obra Iuris ecclesiastici universi recoge el derecho pontifical ${ }^{69}$ y el alemán Anacleto Reinffenstuel, que en su Jus canonicum universum elabora una enciclopedia de derecho canónico muy difundida en el orbe cristiano. ${ }^{70}$

\section{Carácter de la reforma de la vida eclesial en Charcas (1771-1773)}

El Sínodo de Charcas, promovido por un prelado criollo, puso en marcha un proyecto reformista que pretendía relanzar la evangelización y apoyarla sobre un clero secular preparado. Estamos, pues, ante una línea de reforma netamente eclesial. Este proyecto de reforma boliviano afirma apoyarse en las directrices del De Synodo Dioecesana lambertiniano.

Benedicto XIV impulsó desde Roma, ya en los inicios de su pontificado, una renovación de la vida cristiana que enlaza con la reforma triden-

66 Ha sido de importancia relevante en la historia eclesiástica de Venezuela, pues sus Constituciones, impresas en 1698 y reimpresas en 1761, han estado en vigor hasta el siglo XX. Impulsó la catequesis, determinando elaborar un catecismo elemental y otro por preguntas y respuestas, adoptándose como texto oficial, para los más capacitados el Catecismo Romano. También tomaron medidas para la reforma del clero secular, insistiendo en la virtud del desprendimiento y en sus deberes pastorales. Las constituciones sinodales han sido editadas y estudiadas: Gutiérrez de Arce, M.: El sínodo diocesano de Santiago de León de Caracas, Caracas, 1975, 2 vols.; Huerga, Alvaro: "Venezuela: la Iglesia diocesana”, en Borges, Pedro (dir.): Historia de la Iglesia en Hispanoamérica y Filipinas, II,... págs. 375-388, y Egaña, Antonio de: Historia de la Iglesia en la América española. Hemisferio Sur..., págs. 566-571.

67 Véase cita 48.

68 Véase cita 49.

69 Véase cita 51.

70 Véase cita 52. 
tina. Promovió la catequesis y la predicación a los fieles basada en el Catecismo de Trento. ${ }^{71}$

A la vez, la experiencia pastoral de Lambertini le llevó a adoptar medidas concretas para avivar la fe en los cristianos. Entre ellas, la introducción después de cada misa del recitado conjunto del párroco y los fieles de un acto de fe, esperanza y caridad $7^{72}$ y la obligación de predicar con continuidad a los fieles, expresando las condiciones requeridas en el predicador. ${ }^{73}$ Esas experiencias boloñesas de Lambertini fueron recogidas por el sínodo boliviano en el capítulo dedicado a la doctrina (lib. I, tít. 1, cap.1).

Los decretos tridentinos expusieron la doctrina de la misa como sacrificio de la nueva ley, no habían alcanzado a legislar sobre determinados aspectos litúrgicos en línea con esa doctrina. Algunos de ellos fueron señalados en los documentos del papa Lambertini y recogidos por Charcas. ${ }^{74}$

Es sabido que el papa Lambertini trabajó para que sus escritos tuvieran impacto en el mundo católico. Benedicto XIV por medio de sus frecuentes encíclicas estableció una comunicación más directa entre el papa y los obispos. ${ }^{75}$ Dotó a sus encíclicas de un tono personal y dinámico, reco-

71 En palabras del propio papa Lambertini, "quae traduntur in catechismo constituunt regulam; quae adduntur in Pontificali constituunt limitationes regulae": De Synodo Dioecesana, I, 1.7, c. 10, n. 8, cit. en Catecismo Romano, traducción, introducción y notas de Pedro Martín Hernández, Madrid 1956, pág. LIV. Su sucesor, Clemente XIII (1758-1769) ordenó una nueva edición del Catecismo tridentino "que los Romanos Pontífices quisieron proponer a los párrocos como norma de la fe católica y de la enseñanza cristiana" Encíclica En el campo del Señor, de Clemente XIII, en Catecismo para los Párrocos, Texto latino y castellano, traducción y comentarios de Anastasio Machuca Díez, Madrid 1971, pág. XX.

72 Benedicto XIV, Pastoral e Instrucciones Eclesiásticas de... siendo Cardenal Arzobispo de Bolonia, Instrucción LXXII, págs. 98-117 De la obligación de hacer con frecuencia actos de fe, esperanza y caridad. Del modo cómo debe predicarse, enseñando el catecismo: esta medida la tomó Lambertini, recién llegado a Bolonia, al observar que algunos que iban a ser ordenados clérigos no sabían desglosar el contenido de la fe cristiana y afirmaban que el acto de fe explícito era suficiente con hacerlo en contadas ocasiones de la vida.

73 Ibídem, Instrucción IX, págs. 42-52. De tradendis Fidei rudimentis: sobre la predicación dominical; Instrucción $X$, págs. 53-58. De obbligatione, quae Parochi obstringuntur singulis diebus Festis de rebus divinis ad populum verba facere; Instrucción XXVII, págs. 171-179: Pro Archypresbyteris, et Parochis Dioecesanis, atque concinatoribus, qui tempore Quadragesimae ad tradendum Dei Verbum in illorum Ecclesiis designantur.

74 Véase cita 61.

75 Naz sostiene que la expresión "carta encíclica" parece haber sido empleada por vez primera por Benedicto XIV: Epistola encyclica et commonitoria ad omnes episcopos, sur les devoirs de leur charge (Bullarium Benedicti XIV, t. I, Prato, 1845, pág. 3): R. NAZ: Encyclique, en R. NAZ: Dictionnaire de Droit Canonique, V, col. 338-339. Mario Rosa ha destacado el uso frecuente de la encíclica por Benedicto XIV, atribuyéndole el carácter típico que ha asumido en la edad moderna. Cfr. Mario Rosa, Riformatori e ribelli nel..., pág. 60. 
giendo su propia experiencia eclesial, y logró por este medio una espléndida vía de comunicación de ida y vuelta con Roma.

Respecto a la Iglesia americana, Lambertini la conocía bien desde sus años en la curia. Su trabajo en el proceso de canonización de Toribio de Mogrovejo le abrió el panorama de la Iglesia en el Perú. ${ }^{76}$ Como papa, intervino en favor de la situación y la vida religiosa de los americanos, ya en su primer año de gobierno de la Iglesia promulgó la Encíclica Inmensa Pastorum, ${ }^{77}$ dirigida a los obispos de Brasil, Paraguay y Río de la Plata, con fecha 20 de diciembre de 1741, en defensa de la libertad de los indios. Con el Breve Non est quidem, del 25 de mayo de 1754, confirmó el patronato de la Virgen de Guadalupe sobre la Nueva España y ordenó que se celebrara como fiesta solemne el día de su aparición, esto es, el 12 de diciembre. ${ }^{78}$

El Sínodo de Charcas manifiesta que el proyecto lambertiniano encontró una respuesta positiva en el mundo andino. El impulso a la reforma lanzado desde Roma, fue recogido en los decretos sinodales charquenses acerca de los párrocos y doctrineros.

Así pues, en el último tercio del siglo XVIII existieron dos proyectos reformistas de la Iglesia americana. ${ }^{79}$ Uno regalista, impulsado desde Madrid por la Corona, encaminado a hacer de la Iglesia americana instrumento de la política colonial borbónica; y un proyecto autóctono, que parte de la misma Iglesia americana y recoge las instancias de Roma, en continuidad con la reforma tridentina y con las asambleas conciliares y sinodales americanas de los siglos XVI y XVII.

76 "virum adeo singularem (...) peritissimus et virtutum omnium gloria clarissimus semper habitus sit, ipsius legibus, ac Dioecesanis institutis eam saltem fidem atque auctoritatem, vimque, ut ajunt, directivam, adhibendam et adscribendam nemo inficiabitur" ... "pro cuius Canonizatione, cum Promotoris Fidei munus adhuc in minoribus gereremus, plurimum laboris impendibus": Encíclíca Declarasti nobis (1746), en Bullarium Benedicti PP. XIV, t. II, pág. 7.

77 Bullarium Benedictus PP. XIV, t. I, págs. 85-87

78 Alcalá Alvarado, Alfonso: "El acontecimiento guadalupano en la evangelización americana”, en Escudero Imbert, José (Coord.): Historia de la Evangelización de América. Trayectoria, identidad y esperanza de un Continente, Città del Vaticano, 1992, págs. 727-742, aquí pág. 741. Ese mismo año, el 24 de abril aprobó el papa el oficio y la misa propios de la fiesta.

79 Claudio Donati ha señalado también en Italia dos proyectos reformistas, uno eclesial y vinculado a Trento, y otro expresión del absolutismo ilustrado; señala en la década de los años 60 del siglo XVIII el cambio entre ambos proyectos; como hemos visto en Charcas hay una cronología diversa: Donati, Claudio: “Dalla 'Regolata devozione' al 'Giuseppinismo””, págs. 93-94. 
Cabe preguntarse, por último, si tuvieron continuidad los decretos sinodales de Charcas de 1773. Tenemos un dato a favor de su permanencia: las Constituciones sinodales, que hemos estudiado, fueron editadas en Cochabamba en el año 1854, y en la portada consta que esas Constituciones estaban "vijentes en las Diócesis de la República". Tan sólo esa vigencia podría explicar la publicación de los decretos sinodales en una fecha tan tardía.

Maya Sotomayor al estudiar el caso de México encontró una situación similar respecto al IV Concilio provincial mexicano de 1771. Esta autora sostiene la continuidad de la reforma conciliar mexicana en la Iglesia americana del siglo XIX. En Charcas, hemos encontrado indicios de la permanencia de la normativa sinodal de 1773 . Ahora bien, en este punto, se abren interrogantes que exigen una nueva investigación, ¿seguía presente, a mitad del siglo XIX, el impulso renovador de la vida cristiana que hemos visto enunciada por el sínodo charquense del último tercio del XVIII? 